\title{
Leblebi Üretiminde İkinci Kavurma Koşullarının Leblebi'nin Fizikokimyasal Özellikleri ve Duyusal Kalitesi Üzerine Etkisi
}

\author{
Hidayet SAĞLAM ${ }^{1 *}$, Atıf Can SEYDiM ${ }^{2}$ \\ ${ }^{1}$ Kilis 7 Aralık Üniversitesi, Mühendislik-Mimarlık Fakültesi, Gıda Mühendisliği Bölümü, Kilis \\ [ORCID iD: http://orcid.org/0000-0002-1689-8519] \\ ${ }^{2}$ Süleyman Demirel Üniversitesi, Mühendislik Fakültesi, Gıda Mühendisliği Bölümü, Isparta \\ [ORCID iD: http://orcid.org/0000-0003-3808-509X] \\ *Sorumlu yazar: hidayetsaglam@kilis.edu.tr
}

\begin{abstract}
Öz
Nohut (Cicer arietinum L.) zengin protein, diyet lifi, folat, demir ve fosfor gibi bazı minerallerce zengin içeriği nedeniyle beslenme açısından önemlidir. Leblebi, nohudun bazı ön işlemlerden geçtikten sonra farklı sıcaklıklarda kavrulması ile elde edilen ve çerez olarak tüketilen geleneksel bir üründür. Nohuttan leblebi üretimi sürecinde nohutların sınıflandırılması, tavlanması, ıslatılması, kavrulması ve elenmesi gibi işlem aşamalarından geçmesi gerekmektedir. Bu çalışmada, farklı kavurma sıcaklığı ve sürelerinde işlenen nohutlarda görülen kimyasal (protein, karbonhidrat, lif, kül, nem) değişimi incelenmiştir. Duyusal analiz sonuçlarının (çiğ koku, yanık koku, çiğ tat ve yanık tat) değerlendirilmesi ile kavrulan leblebilerin kalitesi belirlenmeye çalışılmıştır. Kavurma sıcaklık ve süreleri ön denemeler sonucunda $150 \pm 5{ }^{\circ} \mathrm{C}, 180 \pm 5$ ${ }^{\circ} \mathrm{C}$ ve $200 \pm 5{ }^{\circ} \mathrm{C} ; 4,6$, ve 8 dakika olarak tespit edilmiştir. Çalışmada tesadüf parselleri deneme deseni kullanılmış ve 3 tekerrürlü olarak gerçekleştirilmiştir. Çalışmanın sonuçlarına göre; kül, lif ve ham protein içerikleri istatistiksel olarak bir değişikliğe uğramamıştır ( $p>0.05)$. Buna karşılık, nem ve toplam nişasta içeriği önemli derecede $(p<0.05)$ azalmıştır. Duyusal analiz sonuçlarına göre; kavurma sıcaklık ve süresinin artması ile birlikte yanık koku ve yanık tat değerinin arttığı, çiğ koku ve çiğ tat özelliklerinin ise azaldığı gözlenmiştir. En çok beğenilen leblebilerin sırasıyla $180 \pm 5{ }^{\circ} \mathrm{C}^{\prime}$ de 8 dakika, $150 \pm 5{ }^{\circ} \mathrm{C}^{\prime}$ de 8 dakika ve $150 \pm 5^{\circ} \mathrm{C}$ 'de 6 dakika kavrulan leblebiler oldukları belirlenmiştir.
\end{abstract}

Anahtar Kelimeler: Nohut, Leblebi, Kavurma, Duyusal analiz

\section{The Effect of Double Roasting Parameters on the Physicochemical Properties and Sensory Quality of Leblebi (A Roasted Chickpea Snack)}

\begin{abstract}
Chickpea (Cicer arietinum L.) are nutritionally important part of the diet due to their protein, carbohydrate, dietary fiber and lower lipid contents. "Leblebi", one of the traditional food product, which is consumed as a snack, is made by roasting of chickpea. At local stores, Leblebi is roasted to its attractive taste and color. Some varieties are available in the market such as salted, peppered and coated with emulsions. The processing steps for making leblebi are cleaning and grading, soaking, tempering (preheating and resting), resting, roasting and dehulling. In this study, the change in chemical (protein, carbohydrate, dietary fiber, ash, moisture content) and sensory properties of chickpeas roasted at different temperature and duration will be investigated. Roasting temperature and duration were selected as $150 \pm 5{ }^{\circ} \mathrm{C}, 180 \pm 5^{\circ} \mathrm{C}$, and $200 \pm 5{ }^{\circ} \mathrm{C} ; 4,6$, and $8 \mathrm{~min}$., respectively, based on preliminary studies. A randomized block design was used. The study was replicated three times using three batches of single roasted leblebi. Statistical analyses of results showed that ash, dietary fiber and protein contents of the samples did not significantly change whereas moisture and total starch content of the samples significantly $(p<0.05)$ decreased. Sensory results demonstrated as roasting temperature and time were increased; burnt flavor and burnt taste were increased, raw flavor and raw taste were
\end{abstract}


decreased. Based on the sensory analysis, the attractive roasted-chickpea found as roasted at $180 \pm 5{ }^{\circ} \mathrm{C}$ 8 minute, $150 \pm 5{ }^{\circ} \mathrm{C} 8$ minute and $150 \pm 5{ }^{\circ} \mathrm{C} 6$ minute, respectively.

Key Words: Chickpeas, Leblebi, Roasting, Sensory analysis

\section{Giriş}

Nohut (Cicer arietinum L.) toprak istekleri az, kurak ve yarı kurak bölgelerde yetişebilen, önemli bir baklagildir. Türkiye'de yetiştirilen yemeklik tane baklagiller içinde nohudun \% 50.27 ekim alanı ve \% 42.12'lük üretim miktarı bulunduğu belirtilmektedir (TÜik, 2016). Üretilen nohudun yaklaşık \% 20 kadarı leblebi üretiminde kullanıldığı ifade edilmektedir (Aydın, 2002).

Çizelge 1. Nohudun besin değerleri (Gençkan, 1958; Gülümser, 1988)

Table 1. Nutritional values of chickpea

\begin{tabular}{|c|c|}
\hline Besin Değeri (Nutritional Value) & $\begin{array}{c}\text { Miktar } \\
\text { (Quantity) }\end{array}$ \\
\hline $\begin{array}{c}\text { Karbonhidrat (\%) } \\
\text { Carbonhydrate (\%) }\end{array}$ & $38.1-73.3$ \\
\hline Protein (Protein) & $17.8-31.2$ \\
\hline Yağ (Oil) & $1.5-6.8$ \\
\hline Selüloz (Cellulose) & $1.6-9.0$ \\
\hline Kül (Ash) & $2.1-11.4$ \\
\hline
\end{tabular}

Nohut; protein, karbonhidrat, ham lif ile bazı mineral ve vitaminlerce zengin bir baklagildir. Aynı zamanda leblebi üretiminde kullanıldığından dolayı önemli bir hammaddedir. Bu ürün hem yemeklik hem de çerezlik ürün olarak ülkemizde ve dünyanın birçok bölgesinde sevilerek tüketilmektedir (Gülümser, 1988). Yemeklik ve çerezlik tüketimi haricinde ayrıca ya taze ya da değişik ürünlere işlenerek tüketilmektedir. Çeşitli metotlara göre işlenebilen nohuttan değişik ürünler elde edilmektedir. Bu metotlar; suda bekletme, kabuğunu çıkarma, öğütme, fermente etme, filizlendirme, haşlama, kavurma, püre etme, kızartma ve buhardan geçirme oldukları belirtilmektedir (Deshpande ve Damodaran, 1990; Köksel ve ark., 1998; Afacan, 2000; Coşkuner ve Karababa, 2004). Çizelge $1^{\prime}$ de nohutların besin içerikleri verilmiştir.

Çizelge 1 'de görüldüğü üzere ülkemizde üretilen nohutların besin değerleri farklılık göstermektedir ve bu durum nohutların farklı çeşitlere sahip olmasından kaynaklanmaktadır. Bu nohutlardan leblebi üretiminde kullanılacak olanlarının şekil, büyüklük, renk ve hasat zamanı gibi belirli özelliklere sahip olması gerekmektedir. Nohutların şekil, büyüklük ve rengi cinse bağlı olarak değişmektedir. Nohutların hasat zamanı ise tavlama işlemini ve son ürün kalitesini etkilemektedir. Nohutlar Kabuli ve Desi çeşidi olarak iki ana çeşit altında toplanmaktadır. Kabuli iri taneli, koç başı biçiminde, Desi çeşidi ise daha küçük taneli, kabuklu ve tam yuvarlak değildir. Desi çeşidi nohutlarda kabuk pembe, Kabuli çeşidinde ise beyazdır. Nohut tanelerinin 21 farklı rengi ve tonu mevcuttur. Kabuli cinsi nohutların proteinlerinden daha fazla yararlanılabilmektedir ve yüksek biyolojik değeri mevcuttur. Türk Standartlarına göre leblebilik nohutlar (Kaba nohut, kuşbaşı nohut) şu şekilde tarif edilmektedir; renkleri daha çok koyuca kırmızımsı sarıdır. Şekilleri kuşbaşını andırmaktadır. Daha çok yuvarlağımsı ve orta iriliktedir. Bu geniş ve derin kısmı tane buruncuğunun hemen altındaki kısma rastlamaktadır. Dip tarafta ikiye bölünmesi pek belirli değildir. Kabuğu oldukça kalın ve az kırışıklıdır. Bu yüzden de kabuk taneden oldukça kolay ayrılmaktadır. Buruncuğu orta boyda ve çengel şeklinde kıvrıktır (Gençkan, 1958; Tekeli, 1965; Bilgir, 
1976; Anonim, 1982; Chavan ve ark., 1983; Gülümser, 1988; Singh, 1997; Jood ve ark., 1998; Aydın, 2002; Coşkuner ve Karababa, 2004).

Nohut çeşitliliği dolayısıyla leblebi üretiminde kullanılacak nohutların kimyasal özellikleri üzerine birçok çalışma yapılmış ve bu çalışmalar sonucunda leblebi üretiminde kullanılabilecek nohutların kimyasal özellikleri tespit edilmiştir. Bu çalışmalardan Tekeli (1965) 'in yaptığı çalışmada; nohudun
\% 10.47 nem, \% 2.43 kül, \% 22.67 protein ve \% 50.88 nişasta içerdiğini belirlenmiştir. Diğer bir çalışmada ise Bilgir, (1976) leblebi üretiminde kullanılacak nohutların \% 7.0911.14 nem, \% 2.52-3.54 kül, \% 25.33-34.05 azotlu madde, \% 50.37-56.34 nişasta ve \% 2.54-4.84 selüloz içermesi gerektiğini belirtmiştir. Nohuttan leblebi oluşumuna kadar geçen sürede nohudun besin değerleri yönünden geçirdiği değişim Çizelge 2'de verilmiştir.

Çizelge 2. Leblebi yapım aşamalarındaki değişimler

Table 2. Changes in the production stages of chickpea

\begin{tabular}{lcccc}
\hline $\begin{array}{c}\text { Besin Değeri (\%) } \\
\text { Nutritional value } \\
\text { (\%) }\end{array}$ & $\begin{array}{c}\text { Ham Nohut } \\
\text { Raw Chickpea }\end{array}$ & $\begin{array}{c}\text { Kavurmadan } \\
\text { Önce } \\
\text { Before roasting }\end{array}$ & $\begin{array}{c}\text { Tek Kavrulmuş } \\
\text { Single roasted }\end{array}$ & $\begin{array}{c}\text { Çifte Kavrulmuş } \\
\text { Double roasted }\end{array}$ \\
\hline Su (Water) & 10.47 & 7.42 & 7.08 & 6.42 \\
Kül (Ash) & 2.43 & 2.52 & 2.64 & 2.80 \\
Protein (Protein) & 22.67 & 22.79 & 24.01 & 22.94 \\
Nişasta (Starch) & 50.88 & 53.30 & 50.44 & 46.33 \\
\hline
\end{tabular}

Nohudun zengin besin içeriğinden dolayı, gelişmekte olan ülkelerde tahıllara katılarak protein/kalori dengesizliğine çözüm sağlanmaktadır. Jambunathan ve ark. (1994)'nın Hindistan'da yaptığı çalışma sonucuna göre, beslenmelerinde sürekli nohut tüketenlerin serum kolesterol değerlerinin tüketmeyenlere oranla düşük olduğunu, ayrıca kalp hastalıklarına yakalanma olasılıklarının daha az olduğunu belirlemişlerdir. Williams ve ark. (1994)'nın çalışmalarında yemeklik tane baklagillerin şişmanlık, kalp damar hastalıkları, hipertansiyon, şeker ve kanser oluşumunu önlediği tespit etmişlerdir.

Ülkemizde leblebi üretimi geleneksel yöntemlerle ve her firmanın kendine özgü üretim aşamaları ile gerçekleştirilmektedir. Tek kavrulmuş leblebi üretimi küçük ölçekli işletmelerde yapılmaktadır. Tek kavrulmuş leblebiler temel olarak şöyle üretilmektedir; $5 \mathrm{~mm}$ boyutunda sınıflandırılmıs nohut 150
${ }^{\circ} \mathrm{C} 30$ dakika tavlanmaktadır. Tavlama işlemi amacıyla16 kg lık her partiye 1.4 ile 1.8 litre olacak şekilde su ilave edilmekte, tava gelip gelmediği elle kontrol edilmekte ve bunun sonucunda soğukluk hissi ile tavlama suyunun yeterliliği anlaşımaktadır. Tavlama işlemi sonucunda nohutlar oda sıcaklığında çuvallar içerisinde 24 saat dinlendirilmektedir. Dinlendirme işleminden sonra $150{ }^{\circ} \mathrm{C} 20$ dakika tavlanmakta ve aynı şekilde 24 saat dinlendirilmektedir. Üçüncü tavlama işleminde ise numuneler $150{ }^{\circ} \mathrm{C} 10$ dakika tavlanmakta ve 2 ay boyunca dinlendirilmektedir. Dinlendirme işlemi bitiminde \%10'luk nem içeriği oluşacak şekilde su ilavesi yapılmakta ve nohutların kabuk atması amacıyla ısıtma işleminden geçirilmektedir. Bu işlem sonucunda "tek kavrulmuş leblebi" elde edilmektedir. Leblebiler tüketime sunulacağı zaman ikinci kavurma işlemi gerçekleştirilmektedir. İinci kavurma işlemi sonucunda çifte kavrulmuş 
leblebi (sarı leblebi) elde edilmektedir (Gülümser,1998; Aydın, 2002).

Sarı leblebi parlak sarı renkli, iri, yumuşak tektürü, ağızda dağılan, dişe yapışmayan özellikte ve kendine has aromada olması gerektiği belirtilmektedir. Ayrıca yanık kokusunun olmaması ve siyah beneklerin az olması tavsiye edilmektedir (Aydın, 2002).

Nohut ve leblebinin yapısal farklılığı, elektron mikroskobu ile yapılan bir çalışmada tespit edilmiştir. Buna göre; nohut içinde hava boşluklarının olmadığı buna karşıık leblebi numunelerinde önemli oranda hava boşluğu olduğu belirlenmiştir. Hava, işleme sırasındaki fiziksel ve kimyasal değişimler sayesinde yapıya dahil olduğu tahmin edildiği belirtilmektedir. Ayrıca, ikinci kavurma işleminden önce eklenen suyun leblebilerin su miktarını arttırdığı, bunun sıvı formdan gaz formuna geçtiği ve suyun buhar basıncı yükseldiği ifade edilmektedir (Köksel ve ark. 1998). Buhar basıncı oluşumu sonunda kavurma sırasındaki nohutların yapısında genişleme gözlenmektedir. Kavurmanın son aşamasında buhar ayrılmakta ve nişastanın suyu uzaklaşmakta, böylece delikli ve suyu çekilmiş bir yapı oluşmaktadır. Yüksek orandaki hava kabarcıklarından dolayı leblebi donuk ve toz şeklinde görünmektedir (Köksel ve ark., 1998; Coşkuner ve Karababa, 2004).

Leblebi üretimi aşamalarında, nohutların karbonhidrat ve protein miktarının ısıl işlem uygulamaları sonucunda azaldığı ve tek kavrulmuş leblebilerin yüzeydeki polisakkaritlerin son kavurma veya benekleme aşamalarında karamelizasyona uğradığı belirtilmektedir (Tekeli, 1965; Gülümser, 1988; Köksel ve ark., 1998; Aydın, 2002; Coşkuner ve Karababa, 2004).

Nohutlar, leblebi üretimi aşamalarında birden fazla ısıl işlem aşamasına tabi tutulmaktadırlar. Isıl işlemden sonra, nem oranının arttırılması amacıyla su eklenmektedir. Kavurma işleminden önce dinlendirilmekte böylece nohutlar yapısal değişikliğe uğramaktadır. Bunun sonucunda son ürünün fiziksel özellikleri etkilenmektedir (Bilgir, 1976; Köksel ve ark., 1998; Coşkuner ve Karababa, 2004).

Gıdaların kavurma veya kurutma sırasındaki davranışı sıcaklık ve ürünün kütle transfer özellikleriyle birlikte değişim göstermektedir. Gıdaların su içerikleri önemli bir kriter olduğundan, kavurma sırasında gıdaların su içeriklerinin kinetiğinin hesaplanmasında ve tahmininde matematiksel modellerden yararlanılmaktadır (Saklar, 1999; Özdemir, 2001). Kinetik modelleme için belirlenmesi gereken ilk parametre reaksiyonun derecesinin belirlenmesidir. Genel itibari ile gıda reaksiyonları 0. ile 3. dereceler arasında oluşmakta fakat enzimatik olmayan esmerleşmeler ya 0 . ya da 1 . dereceden kabul edilmektedirler (Labuza, 1982; Özdemir, 2001).

Ülkemiz için önemli yeri olan leblebinin tanıtımı ve geliştirilmesinde kullanılabilecek çalışmalar yetersizdir. Özellikle leblebilerin kalitesini etkileyen kavurma süre ve sıcaklıkları ile ilgili herhangi bir çalışmaya rastlanmamıştır. Bu araştırma ile kavrulmuş leblebinin kalitesi hakkında önemli bulgular elde edilecektir.

$\mathrm{Bu}$ çalışma ile tek kavrulmuş leblebilere farklı kavurma sıcaklık ve süreleri uygulanarak sarı leblebi üretimi gerçekleştirilmiş ve leblebilerde görülen kimyasal (protein, karbonhidrat, lif, kül, nem) değişimler araştırılarak duyusal sonuçlarla karşılaştırılmıştır. 
Materyal ve Metot

\section{Materyal}

Bu çalışmada, tek kavrulmuş leblebiler Eroğlu Leblebi Tic. Ltd Şti. (Tavşanlı, Kütahya) tarafından temin edilmiştir. Araştırmada kullanılacak tek kavrulmuş leblebi, üretim sonunda çift katı polietilen torbalarda Süleyman Demirel Üniversitesi Gıda
Mühendisliği Bölümü’ne getirilmiştir. Kavurma işlemini takiben leblebiler 1 saat oda sıcaklığında soğutulmuş, sonrasında da analizler tamamlana kadar bariyer özellikli ambalajlara vakum ile paketlenip depolanmıştır. Çifte kavurma işlemine tabi tutulan tek kavrulmuş leblebilerin özellikleri Çizelge 3'te verilmiştir.

Çizelge 3. Tek kavrulmuş leblebilerin özellikleri Table 3. Properties of single roasted chickpea

\begin{tabular}{|c|c|c|c|c|}
\hline \multicolumn{5}{|c|}{ Kimyasal Özellikler (Chemical properties) } \\
\hline $\begin{array}{c}\text { \% Nem } \\
\text { (Moisture) }\end{array}$ & $\begin{array}{c}\text { \% Kül } \\
\text { (Ash) }\end{array}$ & $\begin{array}{c}\text { \% Ham Protein } \\
\text { (Raw protein) }\end{array}$ & $\begin{array}{c}\text { \% Lif } \\
\text { (Dietary } \\
\text { fiber) }\end{array}$ & $\begin{array}{c}\text { \% Nişasta } \\
\text { (Starch) }\end{array}$ \\
\hline $5.33 \pm 2.16$ & $1.95 \pm 0.03$ & $21.05 \pm 0.56$ & $4.21 \pm 0.25$ & $51.26 \pm 3.14$ \\
\hline \multicolumn{5}{|c|}{ Duyusal Özellikler (Sensory properties) } \\
\hline $\begin{array}{c}\text { Çiğ koku } \\
\text { (Raw flavor) }\end{array}$ & $\begin{array}{c}\text { Yanık koku } \\
\text { (Burnt flavor) }\end{array}$ & $\begin{array}{c}\text { Çiğ tat (Raw } \\
\text { taste) }\end{array}$ & $\begin{array}{c}\text { Yanık Tat } \\
\text { (Burnt taste) }\end{array}$ \\
\hline $12.96 \pm 0.43$ & $0.83 \pm 0.15$ & $13.37 \pm 0.27$ & $0.77 \pm 0.18$ \\
\hline
\end{tabular}

Tek kavrulmuş leblebilerin ısıl işleme tabi tutulmalarından önce Islatılmaları gerekmektedir. Islatma amacıyla kullanılan su miktarı tek kavrulmuş leblebilerin nem içeriğini yaklaşık \%8'e ulaştırmıştır. Tek kavrulmuş leblebinin nem oranının \%8'e sabitlenmesi amacıyla kütle dengesi yapılmıştır. Tek kavrulmuş leblebilerden, çifte kavrulmuş leblebi üretilmesi amacıyla uygulanan kavurma sıcaklık ve süreleri ön denemeler sonucunda elde edilmiştir. Bu amaçla $150 \pm 5^{\circ} \mathrm{C}, 180 \pm 5^{\circ} \mathrm{C}$ ve $200 \pm 5^{\circ} \mathrm{C}^{\prime}$ lerde 4,6 ve 8 dakika kavurma işlemi uygulanmıştır.

\section{Metot}

Leblebiler analiz edilmeden önce Moulinex marka gıda öğütücüsü ile öğütülmüş ve analiz edilmişlerdir.

\section{Nem Tayini}

Örneklerin nem tayini AOAC (1997)'ye göre yapılmıştır. Daha önce $130 \pm 3{ }^{\circ} \mathrm{C}$ 'de kurutulup desikatörde soğutularak darası alınmış kuru madde kaplarına $1 \mathrm{mg}$ hassasiyetle 3-5 g numune tartılmıştır.

Sonra $130-133 \quad{ }^{\circ} \mathrm{C}$ ayarlı kurutma dolabında 1 saat kurutulmuştur. Desikatörde oda sıcaklığına kadar soğutularak tartılmıştır. İşlem paralel olarak uygulanmıştır. Yüzde nem (yaş baz, y.b.) aşağıdaki denkleme göre hesaplanmıştır.

$\operatorname{Nem}(\%)=\frac{100(E-M)}{E}$

E: Örneğin başlangıçtaki ağırlığı (g)

M: Örneğin kuru ağırlığı (g)

\section{Kül Miktarı Tayini}

Örneklerin kül miktarı tayini AOAC (1997)'ye göre yapılmıştır. Analizde kullanılacak kroze $900{ }^{\circ} \mathrm{C}$ 'de kül fırınında 
kurutulmuştur. Desikatörde soğutulmuş ve tartılmıştır $\left(A_{1}\right)$. Kroze içerisine 2-5 g kadar öğütülmüş leblebi koyulmuş ve tartılmıştır $\left(A_{2}\right)$. Kül fırınında leblebi numuneleri 900 ${ }^{\circ} \mathrm{C}$ 'de 3 saat yakılmıştır. Desikatöre alınan kroze soğuduktan sonra tartılmış $\left(A_{3}\right)$ ve \% kül kuru madde cinsinden hesaplanmıştır.

\section{Protein Miktarı Tayini}

Örneklerin protein içeriklerinin tespiti amacıyla AOAC (1997)'den faydalanılmış ve metot modifiye edilmiştir. Leblebi örneklerine protein tayini için Kjeldahl metodu uygulanmış ve bu metoda göre 1.25$1.5 \mathrm{~g}$ numune Kjeldahl tüpüne yerleştirilmiştir. Örnek üzerine sırasıyla $15 \mathrm{~g}$ potasyum sülfat, $1 \mathrm{ml}$ bakır sülfat, $25 \mathrm{ml}$ sülfürik asit ilave edildikten sonra 3 saat 15 dakika yakma ünitesinde (Gerhardt, Königswinter, Almanya) kademeli olarak sıcaklık arttırılarak ve nötralizasyon düzeneğine (\% 16'lık NaOH) bağlı olarak yakma işlemi gerçekleştirilmiştir. Yakma işlemi tamamlandıktan sonra tüpler oda sıcaklığına gelinceye kadar soğutulmuştur. Destilasyonda (Gerhardt, Königswinter, Almanya) \% 4'lük indikatörlü borik asitten her örnek için $50 \mathrm{ml}$ kullanılmıştır. Örneklerin distilasyonu amacıyla \% $32^{\prime}$ lik $\quad \mathrm{NaOH}$ kullanılmıştır. Destilasyondan sonra distilat $0.1 \mathrm{~N} \mathrm{HCl}$ ile titre edilerek harcanan miktar kaydedilmiştir. \% Protein miktarı kuru madde cinsinden hesaplanmıştır.

\section{Toplam Lif Miktarı Tayini}

Örneklerin lif içerikleri Bozkurt ve Göğüş (1997)'e göre belirlenmiştir. $5 \pm 0.1 \mathrm{~g}$ un numunesi alınmış ve üzerine $50 \mathrm{ml}$ Bellucchi çözeltisi eklenmiştir. Erlen kaynar su banyosunda un çözülene kadar ısıtılmıştır. Erlen su banyosundan çıkarılmış ve ocağa konmuştur. Erlene geri soğutma bağlanmıştır. Hafif ateşteki ocakta 25 dakika bekletilmiş, bekleme sırasında karıştırma işlemi yapılmıştır. Aynı zamanda kurutma kabı ve külsüz filtre kâğıdı (Whatman No: 41) 103-105 ${ }^{\circ} \mathrm{C}^{\prime}$ lerde sabit tartıma gelene kadar kurutulmuştur. Kroze $W_{1}$ ve filtre kâğıdı $W_{2}$ olarak kaydedilmiştir. Tartılmış filtre kâğıdı ile sıcak çözelti süzülmüştür. Filtre üzerindeki katı kısım $5 \mathrm{ml}$ Belluchi çözeltisi, sonra kaynar su, daha sonra sırasıyla ikişer defa 5 $\mathrm{ml}$ etanol ve $10 \mathrm{ml}$ petrol eter ile yıkanmıştır. Filtre kâğıdı tartılan krozeye yerleştirilip, 103$105{ }^{\circ} \mathrm{C}$ 'de sabit tartıma gelene kadar kurutulmuştur. Kurutma kabı içeriği kuruduktan sonra tartılmış ve $W_{3}$ olarak kaydedilmiştir. Başka bir kroze 500-550 ${ }^{\circ} \mathrm{C}$ 'de sabit ağırlığa gelene kadar kurutulmuş ve tartılarak $W_{4}$ olarak kaydedilmiştir. Kurutulmuş filtre kağıdı ve içindeki maddeler tartılan krozeye konmuş ve $500-550^{\circ} \mathrm{C}^{\prime}$ de 2 saat boyunca yakılmıştır. 2 saat sonunda kroze tartılmış ve $W_{5}$ olarak kaydedilmiştir. Hesaplama aşağıdaki formüle göre düzenlenmiştir.

\%Ham Lif $=\frac{\left\{\left(W_{3}-W_{1}\right)-\left[\left(W_{5}-W_{4}\right)+W_{2}\right]\right\}}{W} * 100$

\section{Toplam Nişasta Miktarı Tayini}

Örneklerin toplam nişasta içerikleri Uluöz (1965)'e göre tespit edilmiştir. Buna göre kullanılan kimyasallar ve çözeltiler aşağıdaki gibidir:

Carrez l: $106 \mathrm{~g}$ potasyum ferrosiyanür $\left[\mathrm{K}_{4} \mathrm{Fe}(\mathrm{CN})_{6} 3 \mathrm{H}_{2} \mathrm{O}\right]$ saf su ile $1000 \mathrm{ml}$ 'ye tamamlanır.

Carrez II: 219 g çinko asetat $\left[\left(\mathrm{CO}_{3} \mathrm{COO}\right) \mathrm{Zn}_{2} \mathrm{H}_{2} \mathrm{O}\right]$ ve $30 \mathrm{~g}$ asetik asit [ $\left.\mathrm{CH}_{3} \mathrm{COOH}\right]$ saf su içinde çözülür ve $1000 \mathrm{ml}$ ye tamamlanır.

$1 \mathrm{M} \mathrm{HCl}: 2.56 \mathrm{ml} \mathrm{HCl} 100 \mathrm{ml}$ ye tamamlanır ( $\mathrm{HCl} ; \mathrm{d}: 1.19, \mathrm{~V}: \% 37)$.

Gerekli çözeltiler hazırlandıktan sonra 25 g örnek 100 ml'lik balonjojeye tartılmıştır. 
Üzerine $50 \mathrm{ml} 1 \mathrm{M} \mathrm{HCl}$ eklenmiş ve iyice çalkalanmıştır. Kaynamakta olan su banyosuna konmuştur. Burada birkaç dakika bekledikten sonra iyice çalkalanmış ve kaynar su banyosunda 15 dakika bekletilmiştir. Bu süre sonunda $15-20 \mathrm{ml}$ saf su eklenmiş ve çeşme suyu ile oda sıcaklı̆ına soğutulmuştur. Balona $5 \mathrm{ml}$ Carrez I eklenerek tekrar çalkalanmış ve birkaç dakika bekletilmiştir. Daha sonra $5 \mathrm{ml}$ Carrez II eklenmiş ve çalkalanarak birkaç dakika beklemeye bırakılmıştır. Balon saf su ile 100 ml'ye tamamlanmıştır. Balon içeriği filtre kağıdından süzülüp berrak bir süzüntü elde edilmiştir. Süzüntü polarimetre tüplerine hava kabarcı̆̆ı kalmayacak şekilde doldurulmuştur ve polarimetrede okunmuştur (N). Sonuç aşağıda verilen formül ile hesaplanmıştır:

$\%$ Nişasta $=N * 10.983$

Bu formüle göre;

$\mathrm{N}$ : Polarimetrede okunan değer

10.9830: sabit değer (Kullanılan polarimetre tüpü uzunluğu; 200 mm, Nohut Nişastası sabiti; 182.1)

\section{Leblebi Örneklerinin Duyusal Analizleri}

Leblebilerin duyusal değerlendirilmesinde "Tanımlayıcı Analiz Yöntemi" kullanılmıştır. Tanımlayıcı Analiz Yöntemi diğer analiz yöntemlerine göre ayrıntılı bir yöntemdir. Bu nedenle çalışmada kullanılacak tanımlayıcı kelimeleri belirlemek amacıyla piyasadan temin edilen farklı leblebi numuneleri ile 23 paneliste eğitim verilmiştir. Eğitimdeki amaç uygulamada kullanılan materyali tanıtmak ve ortak çalışarak tanımlayıcı kelimeleri oluşturmaktır. Eğitimden sonra, piyasadan temin edilen leblebi numuneleri özel olarak ayarlanmış panel odalarında tuzlu kraker ve suyla birlikte sunulmuştur. Örnekler paralelli olarak çalışılmıştır. Duyusal test sırasında numune farklııklarını tespit edemeyen panelistler ön deneme sonunda değerlendirme dışı bırakılmıştır.

Çalışmada çiğ koku, yanık koku, çiğ tat ve yanık tat gibi kelimeler araştırmanın örnekleme dağılımına ve amacına bağlı kalınarak tanımlayıcı kelimeler olarak panelistler tarafından tespit edilmiştir. Sonuçların değerlendirilmesi amacıyla 15 cm'lik ölçek kullanılmıştır.

\section{istatistik}

$\mathrm{Bu}$ çalışmanın deneme deseni tesadüf blokları içinde $3 \times 3$ faktöriyel düzenleme (rasgeleleştirilmiş öbek içinde $3 \times 3$ etmensel deney tasarımı) (Randomize complete block design with factorial arrangements) olarak seçilmiştir. Bu çalışma üç tekerrür şeklinde düzenlenmiş, analizler ise paralelli olarak yapılmıştır. Araştırma sonuçları varyans analizi (General Linear Model) ile incelenmiştir. Ortalamaların farkının önemli $(p<0,05)$ olup olmadığı DUNCAN çok yönlü değişim testi ile belirlenmiştir. Ayrıca değerler arasındaki korelasyon (PROC CORR) incelenmiştir (SAS, 2003).

\section{Araştırma Bulguları ve Tartışma}

\section{Kavurma Sırasındaki Nem Kaybı}

Leblebi kavurma işlemi sırasında uygulanan sıcaklık ve süreler önemli düzeyde $(p<0.001)$ nem farklılıklarına neden olduğu belirlenmiştir. Kavurma sıcaklıkları artarken leblebilerinin nem içeriklerinin azaldığı tespit edilmiştir. Aynı sıcaklıktaki leblebilerin kavurma sürelerinin artması sonucu yüzde nem içeriklerinin önemli düzeyde azaldığı görülmüştür (Şekil 1). 


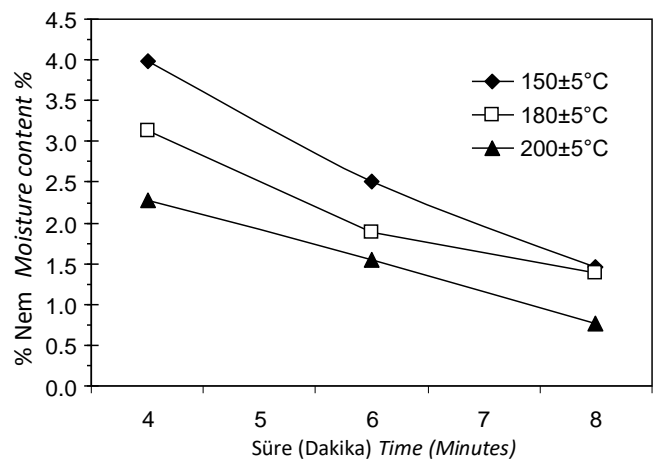

Şekil 1. Leblebilerin \% nem değişimi

Figure 1. Moisture Content of Chickpea

$150 \pm 5{ }^{\circ} \mathrm{C}^{\prime}$ de 4 dakika kavrulan leblebilerin nemi \% 3.98 iken, $150 \pm 5{ }^{\circ} \mathrm{C} 8$ dakika kavrulan leblebilerin nemi \% 1.46 olarak tespit edilmiştir. $180 \pm 5{ }^{\circ} \mathrm{C}^{\prime}$ de 4 dakika kavrulan leblebilerin nem içerikleri \% 3.13 iken, 180 \pm 5 ${ }^{\circ} \mathrm{C}^{\prime}$ de 8 dakika kavrulan leblebilerin nem içerikleri \% 1.38'e düştüğü tespit edilmiştir. Kavurma işlemi öncesinde \% 8'e ayarlanan leblebi nemi $200 \pm 5{ }^{\circ} \mathrm{C}^{\prime}$ de 8 dakika kavrulma sonucu nem içeriği olan \% 0.77 'e düştüğü görülmüştür (Çizelge 4).

Kavrulma sırasındaki nem değişim kinetik modelini göstermek amacıyla sıfırıncı $\left(0^{\circ}\right)$ ve birinci $\left(1^{\circ}\right)$ dereceden denklemler deneysel olarak elde edilen nem değerlerine uygulanmıştır. Buna göre nem değerinin sıfırıncı dereceden regresyon sonuçları $\left(r^{2}\right)$ 0.9423-0.9999 arasında, birinci dereceden $r^{2}$ değerleri ise 0.9751-0.9978 arasında tespit edilmiştir. Modellerin r2 değerlerine göre, nem değişim kinetiği sıfırıncı dereceden kabul edilmiştir. Ayrıca nem değişiminin aktivasyon enerjisi $17.28 \mathrm{kj} / \mathrm{mol}$ olduğu hesaplanmıştır.

Çizelge 4. \% Nem içeriği

Table 4. \% Moisture content

\begin{tabular}{|c|c|c|c|c|}
\hline \multicolumn{5}{|c|}{$\%$ Nem (Moisture content) } \\
\hline $\begin{array}{c}\text { Tek Kavrulmuş Leblebi } \\
\text { (Once Roasted Chickpea) }\end{array}$ & \multicolumn{4}{|c|}{$\begin{array}{c}\text { Çifte Kavrulmuş Leblebi } \\
\text { (Double Roasted Chickpea) }\end{array}$} \\
\hline \multirow{3}{*}{$5.33 \pm 2.16$} & $\begin{array}{c}\text { Sıcaklık } \\
(\text { Temperature) })\end{array}$ & $\begin{array}{c}\text { 4 dakika } \\
(4 \text { minutes })\end{array}$ & $\begin{array}{c}\text { 6 dakika } \\
(6 \text { minutes) }\end{array}$ & $\begin{array}{c}\text { 8 dakika } \\
(8 \text { minutes) }\end{array}$ \\
\cline { 2 - 5 } & $150 \pm 5^{\circ} \mathrm{C}$ & $3.98 \pm 0.01^{\mathrm{a}, \mathrm{x}}$ & $2.51 \pm 0.35^{\mathrm{b}, \mathrm{x}}$ & $1.46 \pm 0.04^{\mathrm{c}, \mathrm{x}}$ \\
\cline { 2 - 5 } & $180 \pm 5^{\circ} \mathrm{C}$ & $3.13 \pm 0.86^{\mathrm{a}, \mathrm{y}}$ & $1.88 \pm 0.79^{\mathrm{b}, \mathrm{y}}$ & $1.38 \pm 0.61^{\mathrm{c}, \mathrm{y}}$ \\
\cline { 2 - 5 } & $200 \pm 5^{\circ} \mathrm{C}$ & $2.28 \pm 0.00^{\mathrm{a}, \mathrm{z}}$ & $1.54 \pm 0.25^{\mathrm{b}, \mathrm{z}}$ & $0.77 \pm 0.06^{\mathrm{c}, \mathrm{z}}$ \\
\hline
\end{tabular}

a-c satırlarda önemli düzeydeki $(p<0.05)$ farklılıkların üst simgelerini ifade etmektedir

a-c represents the top symbols of the differences in the significant $(p<0.05)$ differences in the lines

$x-z$ sutunda önemli düzeydeki $(p<0.05)$ farklılıkların üst simgelerini ifade etmektedir

$x-z$ represents the top symbols of the differences in the significant $(p<0.05)$ differences in the column.

Bir reaksiyonun aktivasyon enerjisi, reaksiyon hızının sıcaklığa bağlı haldeki değişim düzeyini göstermektedir. Bir reaksiyonun aktivasyon enerjisinin yüksek olması, bu reaksiyonun sıcaklık değişimine çok hassas olduğunun bir kanıtıdır. Kül Miktarındaki Değişim
Elde edilen sonuçların değerlendirilmeleri sonucunda farklı kavurma sıcaklık ve sürelerinin kül değerlerini etkilemediği tespit edilmiştir. Elde edilen sonuçlara göre numunelerin kül içerikleri \% 1.85-1.95 aralığında oldukları belirlenmiştir (Çizelge 5). 
Çizelge 5. Numunelerin kül değerleri

Table 5. Ash values of chickpea

\begin{tabular}{|c|c|c|c|c|}
\hline \multicolumn{5}{|c|}{ \% Kül (Ash \%) } \\
\hline $\begin{array}{c}\text { Tek Kavrulmuş Leblebi } \\
\text { (Once Roasted Chickpea) }\end{array}$ & \multicolumn{4}{|c|}{$\begin{array}{c}\text { Çifte Kavrulmuş Leblebi } \\
\text { (Double Roasted Chickpea) }\end{array}$} \\
\hline \multirow{3}{*}{$1.95 \pm 0.03$} & $\begin{array}{c}\text { Sıcaklık } \\
\text { (Temperature) }\end{array}$ & $\begin{array}{c}\text { 4 dakika } \\
(4 \text { minutes) }\end{array}$ & $\begin{array}{c}\text { 6 dakika } \\
(6 \text { minutes) }\end{array}$ & $\begin{array}{c}\text { 8 dakika } \\
(8 \text { minutes) }\end{array}$ \\
\cline { 2 - 5 } & $150 \pm 5^{\circ} \mathrm{C}$ & $1.85 \pm 0.12^{\mathrm{a}, \mathrm{x}}$ & $1.87 \pm 0.10^{\mathrm{a}, \mathrm{x}}$ & $1.86 \pm 0.10^{\mathrm{a}, \mathrm{x}}$ \\
\cline { 2 - 5 } & $180 \pm 5^{\circ} \mathrm{C}$ & $1.89 \pm 0.80^{\mathrm{a}, \mathrm{x}}$ & $1.93 \pm 0.16^{\mathrm{a}, \mathrm{x}}$ & $1.93 \pm 0.60^{\mathrm{a}, \mathrm{x}}$ \\
\cline { 2 - 5 } & $200 \pm 5^{\circ} \mathrm{C}$ & $1.86 \pm 0.03^{\mathrm{a}, \mathrm{x}}$ & $1.92 \pm 0.03^{\mathrm{a}, \mathrm{x}}$ & $1.90 \pm 0.03^{\mathrm{a}, \mathrm{x}}$ \\
\hline
\end{tabular}

\section{Ham Protein Sonuçları}

Kavurma sıcaklık ve sürelerinin etkisi ile numunelerde toplam ham protein oranlarında önemli düzeyde değişim tespit edilememiştir. Tek kavrulmuş leblebiler; $200 \pm 5{ }^{\circ} C^{\prime}$ de 4 dakika kavrulduklarında ham protein içeriği \% 21.55, $200 \pm 5{ }^{\circ} \mathrm{C}^{\prime}$ de 6 dakika kavrulduklarında ise \% 19.09 olarak tespit edilmiştir. Aynı kavurma sıcaklığında, kavurma süresinin artması ile \% ham protein değerlerinde azalmalar söz konusu olmasına rağmen bu değişim istatistiksel olarak bir anlam ifade etmediği belirtilmektedir. Farklı kavurma sıcaklığı ve süresinde kavrulan leblebilerin \% ham protein içerikleri \% 19.0921.55 arasında değişim göstermiştir (Çizelge $6)$.

Farklı ürünlerin kavrulmaları üzerine yapılan çalışmalarda, kavurma işlemlerinin protein içeriklerini etkilemediği belirtilmektedir (Kırbaşlar, 1998; Köroğlu ve ark., 2000).

Çizelge 6. Leblebilerin \% ham protein değerleri

Table 6. Crude protein values of chickpea

\begin{tabular}{|c|c|c|c|c|}
\hline \multicolumn{5}{|c|}{ \% Ham protein (\% Crude protein) } \\
\hline $\begin{array}{c}\text { Tek Kavrulmuş Leblebi } \\
\text { (Once Roasted Chickpea) }\end{array}$ & \multicolumn{4}{|c}{$\begin{array}{c}\text { Cifte Kavrulmuş Leblebi } \\
\text { (Double Roasted Chickpea) }\end{array}$} \\
\hline \multirow{3}{*}{$21.05 \pm 0.56$} & $\begin{array}{c}\text { Sicaklık dakika } \\
\text { (Temperature) }\end{array}$ & $\begin{array}{c}\text { 4 dakika } \\
\text { (4 minutes) }\end{array}$ & $\begin{array}{c}\text { 6 dakika } \\
\text { (6 minutes) }\end{array}$ & $\begin{array}{c}\text { 8 dakika } \\
\text { (8 minutes) }\end{array}$ \\
\cline { 2 - 5 } & $150 \pm 5^{\circ} \mathrm{C}$ & $20.48 \pm 1.6^{\mathrm{a}, \mathrm{x}}$ & $20.87 \pm 0.8^{\mathrm{a}, \mathrm{x}}$ & $20.13 \pm 0.46^{\mathrm{a}, \mathrm{x}}$ \\
\cline { 2 - 5 } & $180 \pm 5^{\circ} \mathrm{C}$ & $20.02 \pm 0.67^{\mathrm{a}, \mathrm{x}}$ & $19.73 \pm 0.28^{\mathrm{a}, \mathrm{b}, \mathrm{x}, \mathrm{y}}$ & $19.42 \pm 0.65^{\mathrm{b}, \mathrm{x}}$ \\
\cline { 2 - 5 } & $200 \pm 5^{\circ} \mathrm{C}$ & $21.55 \pm 0.94^{\mathrm{a}, \mathrm{x}}$ & $19.09 \pm 2.06^{\mathrm{a}, \mathrm{y}}$ & $19.15 \pm 2.56^{\mathrm{a}, \mathrm{y}}$ \\
\hline
\end{tabular}

${ }^{a-c}$ satırlarda önemli düzeydeki $(p<0.05)$ farklılıkların üst simgelerini ifade etmektedir.

${ }^{a-c}$ represents the top symbols of the differences in the significant $(p<0.05)$ differences in the lines

${ }^{x-z}$ sutunda önemli düzeydeki $(p<0.05)$ farklılıkların üst simgelerini ifade etmektedir

${ }^{x-z}$ represents the top symbols of the differences in the significant $(p<0.05)$ differences in the column

\section{Lif Sonuçları}

Farklı sıcaklık ve sürelerde çifte kavrulmuş leblebilerin \% lif değerleri incelendiğinde, 4 dakikalık uygulamada $150 \pm 5^{\circ} \mathrm{C}^{\prime}$ de kavrulan leblebiler ile diğer sıcaklıklarda kavrulanlar arasında önemli düzeyde $(p<0.05)$ farklılık belirlenmiştir. Benzer şekilde 6 dakikalık kavurma işlemi sonucunda $150 \pm 5^{\circ} \mathrm{C}^{\prime}$ de kavrulan leblebilerin $180 \pm 5^{\circ} \mathrm{C}^{\prime}$ de kavrulan leblebilerden önemli düzeyde $(p<0.05)$ farklılık belirlenmiştir. 8 dakikalık uygulama sonucunda ise $150 \pm 5^{\circ} \mathrm{C}^{\prime}$ lik kavurma işlemi $200 \pm 5^{\circ} \mathrm{C}^{\prime}$ lik kavurma işleminden önemli düzeyde farklılık gösterdiği tespit edilmiştir 
$(\mathrm{p}<0.05)$. Numunelerin lif değerleri \%4.214.77 aralığında değişim gösterdiği belirlenmiştir (Çizelge 7). Oosterrveld (2003)'in kahvenin kavrulması üzerine yaptığı çalışmada, kavurma işleminin selülozu etkilemediğini tespit etmiştir.

Çizelge 7. Lif değerleri

Table 7. Dietary fiber values

\begin{tabular}{|c|c|c|c|c|}
\hline \multicolumn{4}{|c|}{ \% Lif (\% Dietary fiber) } \\
\hline $\begin{array}{c}\text { Tek Kavrulmuş Leblebi } \\
\text { (Once Roasted Chickpea) }\end{array}$ & \multicolumn{4}{|c|}{$\begin{array}{c}\text { Çifte Kavrulmuş Leblebi } \\
\text { (Double Roasted Chickpea) }\end{array}$} \\
\hline \multirow{4}{*}{$4.21 \pm 0.25$} & $\begin{array}{c}\text { Sıcaklık } \\
\text { (Temperature) }\end{array}$ & $\begin{array}{c}\text { 4 dakika } \\
(4 \text { minutes) }\end{array}$ & $\begin{array}{c}\text { 6 dakika } \\
(6 \text { minutes) }\end{array}$ & $\begin{array}{c}\text { 8 dakika } \\
(8 \text { minutes) }\end{array}$ \\
\cline { 2 - 5 } & $150 \pm 5^{\circ} \mathrm{C}$ & $4.56 \pm 0.64^{\mathrm{a}, \mathrm{x}}$ & $4.53 \pm 0.75^{\mathrm{a}, \mathrm{b}, \mathrm{x}}$ & $4.67 \pm 0.62^{\mathrm{b}, \mathrm{x}}$ \\
\cline { 2 - 5 } & $180 \pm 5^{\circ} \mathrm{C}$ & $4.71 \pm 0.21^{\mathrm{a}, \mathrm{x}, \mathrm{y}}$ & $4.72 \pm 0.40^{\mathrm{b}, \mathrm{y}}$ & $4.77 \pm 0.77^{\mathrm{b}, \mathrm{x}, \mathrm{y}}$ \\
\cline { 2 - 5 } & $200 \pm 5^{\circ} \mathrm{C}$ & $4.61 \pm 0.40^{\mathrm{a}, \mathrm{y}}$ & $4.47 \pm 0.75^{\mathrm{a}, \mathrm{x}, \mathrm{y}}$ & $4.76 \pm 0.18^{\mathrm{a}, \mathrm{y}}$ \\
\hline
\end{tabular}

a-c satırlarda önemli düzeydeki ( $\mathrm{p}<0.05$ ) farklılıkların üst simgelerini ifade etmektedir

${ }^{a-c}$ represents the top symbols of the differences in the significant $(p<0.05)$ differences in the lines

${ }^{x-z}$ sutunda önemli düzeydeki $(p<0.05)$ farklılıkların üst simgelerini ifade etmektedir

$x-z$ represents the top symbols of the differences in the significant $(p<0.05)$ differences in the column

Toplam Nişasta Sonuçları

Nişasta değerleri incelendiğinde uygulanan kavurma sıcaklığının nişasta değerlerini etkilediği sonucuna varılmıştır. Aynı kavurma sıcaklığında kavurma süreleri artan leblebilerin nişasta oranlarında önemli düzeyde azalma tespit edilmiştir. Tek kavrulmuş leblebilerin nişasta içeriği \% 51.26 iken, $150 \pm 5{ }^{\circ} \mathrm{C}^{\prime}$ de 4 dakika kavrulan leblebilerin \% 51.44, $150 \pm 5{ }^{\circ} \mathrm{C} 8$ dakika kavrulan leblebilerin nişasta değeri ise \%
46.82 olduğu belirlenmiştir. $180 \pm 5{ }^{\circ} \mathrm{C}^{\prime}$ de 4 dakika kavrulan leblebilerin nişasta içerikleri \% 46.68 iken, $200 \pm 5{ }^{\circ} \mathrm{C}^{\prime}$ de 4 dakika kavrulduklarında nişasta içerikleri \% 37.78'e düşmektedir. $150 \pm 5^{\circ} \mathrm{C}$ 'de 4 dakika kavrulan leblebilerin nişasta içerikleri \% 51.44 ile en yüksek nişasta içeriğine sahipken, gözlenen en düşük nişasta içeriği $200 \pm 5{ }^{\circ} \mathrm{C}^{\prime}$ de 8 dakika kavrulan leblebilerde nişasta içeriği \% 33.66 olarak tespit edilmiştir (Çizelge 8).

Çizelge 8. Leblebilerin nişasta içerikleri

Table 8. The starch content of roasted chickpeas

\begin{tabular}{|c|c|c|c|c|}
\hline \multicolumn{5}{|c|}{$\%$ Nişasta (\% Starch) } \\
\hline $\begin{array}{c}\text { Tek Kavrulmuş Leblebi } \\
\text { (Once Roasted Chickpea) }\end{array}$ & \multicolumn{4}{|c}{$\begin{array}{c}\text { Çifte Kavrulmuş Leblebi } \\
\text { (Double Roasted Chickpea) }\end{array}$} \\
\hline \multirow{3}{*}{$51.26 \pm 3.14$} & $\begin{array}{c}\text { Sıcaklık } \\
(\text { Temperature) }\end{array}$ & $\begin{array}{c}\text { 4 dakika } \\
(4 \text { minutes) }\end{array}$ & $\begin{array}{c}\text { 6 dakika } \\
(6 \text { minutes) }\end{array}$ & $\begin{array}{c}\text { 8 dakika } \\
(8 \text { minutes) }\end{array}$ \\
\cline { 2 - 6 } & $150 \pm 5^{\circ} \mathrm{C}$ & $51.44 \pm 1.44^{\mathrm{a}, \mathrm{x}}$ & $46.96 \pm 2.98^{\mathrm{b}, \mathrm{x}}$ & $46.82 \pm 2.81^{\mathrm{b}, \mathrm{x}}$ \\
\cline { 2 - 6 } & $180 \pm 5^{\circ} \mathrm{C}$ & $46.68 \pm 0.73^{\mathrm{a}, \mathrm{y}}$ & $46.37 \pm 0.66^{\mathrm{b}, \mathrm{x}}$ & $39.83 \pm 1.82^{\mathrm{b}, \mathrm{y}}$ \\
\cline { 2 - 6 } & $200 \pm 5^{\circ} \mathrm{C}$ & $37.88 \pm 1.52^{\mathrm{a}, \mathrm{z}}$ & $36.59 \pm 1.59^{\mathrm{b}, \mathrm{z}}$ & $33.66 \pm 1.24^{\mathrm{b}, \mathrm{z}}$ \\
\hline
\end{tabular}

${ }^{a-c}$ satırlarda önemli düzeydeki $(\mathrm{p}<0.05)$ farklılıkların üst simgelerini ifade etmektedir

${ }^{a-c}$ represents the top symbols of the differences in the significant $(p<0.05)$ differences in the lines

${ }^{x-z}$ sutunda önemli düzeydeki $(p<0.05)$ farklılıkların üst simgelerini ifade etmektedir

${ }^{x-z}$ represents the top symbols of the differences in the significant $(p<0.05)$ differences in the column

Birçok üründe kavurma işlemi sonunda nişasta içeriğinin elde ettiğimiz sonuçlara benzer şekilde azalma gösterdiği belirtilmektedir. $\mathrm{Bu}$ çalışmaların birinde 
fındığın $135{ }^{\circ} C^{\prime}$ de zamana bağlı olarak kavrulması ile nişasta içeriklerinde bir değişiklik gözlenmemesine rağmen 20 . dakikadan itibaren toplam şeker oranlarında azalmalar görüldüğü ifade edilmektedir. Diğer bir çalışmada ise kahve çekirdeklerinin kavrulması sonucu içeriklerinde bulunan polisakkaritlerde azalmalar tespit etmişlerdir (Kırbaşlar, 1998; Redgwell ve ark., 2002).

Nişastanın azalmasının nedeni bir kısım nişastanın kendisini oluşturan mono- ve disakkaritlere dönüşmesi ile açılanabilmektedir. Nohut ile leblebinin tatlılık özelliklerinin karşılaştırılması halinde, leblebinin daha şekerli olmasının ancak ortamdaki mono- ve disakkarit miktarının artmasından kaynaklanabileceğini düşündürmektedir.

\section{Duyusal Analiz Sonuçları}

Duyusal analiz sonuçları, panelistlerin duyusal değerlendirme formunda daha önceden tanımlanmış çiğ koku, yanık koku, çiğ tat ve yanık tat gibi kelimelerin bulunduğu cetvelde verdikleri cevapların istatistiksel değerlendirilmeleri sonucu belirlenmiştir (Çizelge 9).

\section{Çiğ Koku}

Sonuçlar kavurma sıcaklık ve sürelerinin leblebilerin çiğ kokusunu çok önemli düzeyde $(p<0.0001)$ etkilediğini göstermiştir. Tek kavrulmuş leblebinin çiğ koku değeri 12.96 iken, $150 \pm 5{ }^{\circ} \mathrm{C}^{\prime}$ de 4 dakika kavrulan leblebinin çiğ koku değeri 10.20, 8 dakika kavrulanınki ise 1.65 olarak tespit edilmiştir. Buna göre $150-200{ }^{\circ} \mathrm{C}$ aralığında ve 4 dakika kavrulan leblebilerin çiğ koku değerleri 1.6510.20 aralığında olabileceği belirtilmektedir (Şekil 2; Çizelge 9). Leblebilerin kavrulması

Çizelge 9. Numunelerin Duyusal Analiz Sonuçları Table 9. Results of sensory Analysis sonucunda leblebilerin çiğ kokusunun azaldığı sonucuna varılmıştır.

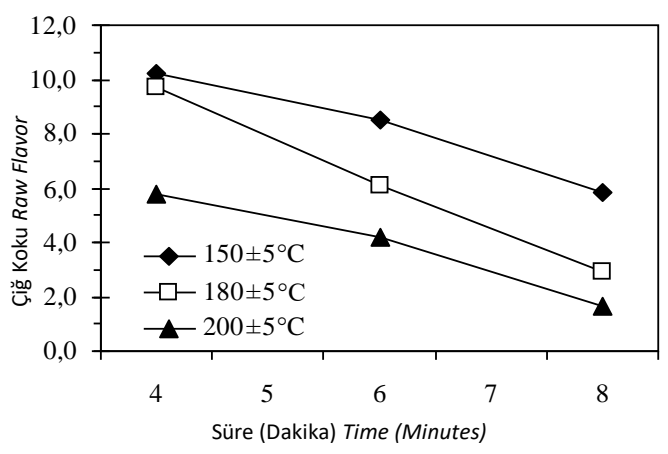

Şekil 2. Leblebilerin çiğ koku değişim grafiği

Figure 2. Raw flavor of roasted chickpea

\section{Yanık Koku}

Farklı kavurma sıcaklık ve sürelerinin leblebilerin yanık kokusunu çok önemli düzeyde $\quad(p<0.0001) \quad$ etkilediği tespit edilmiştir. Elde edilen sonuçlar leblebilerin çiğ kokusunun tam zıttı şeklinde olduğu, sıcaklığın artması ile yanık kokunun arttığı görülmüştür. Buna göre tek kavrulmuş leblebilerin yanık kokusu 0.83 iken, $200 \pm 5$ ${ }^{\circ} \mathrm{C}$ 'de 4 dakika kavrulan leblebinin yanık koku değeri 7.61, 8 dakika kavrulan leblebinin yanık kokusu ise 12.85 olarak tespit edilmiştir (Şekil 3; Çizelge 9).

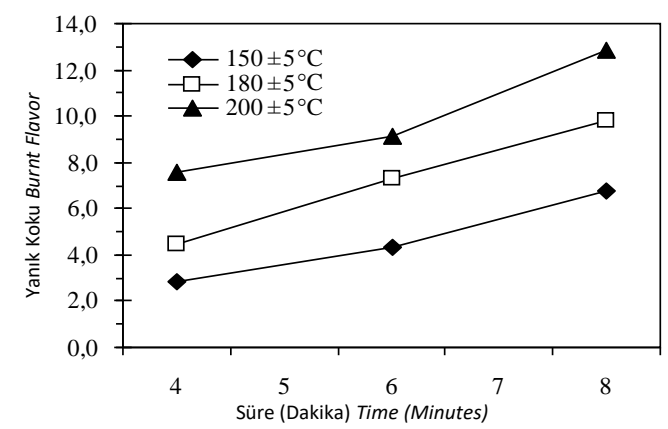

Şekil 3. Leblebilerin yanık koku değişim grafiği

Figure 3. Burnt flavor of roasted chickpea 


\begin{tabular}{|c|c|c|c|c|c|c|}
\hline & $\begin{array}{c}\text { Kavurma Sıcaklığı } \\
\text { (Roasting } \\
\text { Temperature) }\end{array}$ & $\begin{array}{c}\text { Süre } \\
\text { (Dakika) } \\
\text { (Time, } \\
\text { Minute) }\end{array}$ & $\begin{array}{l}\text { Çiğ koku } \\
\text { (Raw flavor) }\end{array}$ & $\begin{array}{l}\text { Yanık koku } \\
\text { (Burnt } \\
\text { flavor) }\end{array}$ & $\begin{array}{c}\text { Çiğ tat } \\
\text { (Raw taste) }\end{array}$ & $\begin{array}{c}\text { Yanık Tat } \\
\text { (Burnt } \\
\text { taste) }\end{array}$ \\
\hline \multirow{9}{*}{ 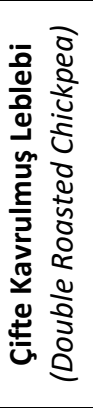 } & \multirow{3}{*}{$150 \pm 5^{\circ} \mathrm{C}$} & 4 & $10.20 \pm 1.98$ & $2.85 \pm 1.10$ & $10.21 \pm 1.73$ & $3.00 \pm 1.38$ \\
\hline & & 6 & $8.54 \pm 1.54$ & $4.32 \pm 1.03$ & $8.48 \pm 1.49$ & $4.37 \pm 0.91$ \\
\hline & & 8 & $5.85 \pm 0.66$ & $6.77 \pm 1.64$ & $5.88 \pm 1.07$ & $6.63 \pm 2.45$ \\
\hline & \multirow{3}{*}{$180 \pm 5^{\circ} \mathrm{C}$} & 4 & $9.73 \pm 0.54$ & $4.49 \pm 2.25$ & $9.51 \pm 0.18$ & $3.22 \pm 0.40$ \\
\hline & & 6 & $6.09 \pm 2.22$ & $7.27 \pm 2.63$ & $6.10 \pm 2.38$ & $6.75 \pm 3.41$ \\
\hline & & 8 & $2.92 \pm 1.31$ & $9.79 \pm 2.56$ & $2.77 \pm 1.20$ & $11.41 \pm 1.45$ \\
\hline & \multirow{3}{*}{$200 \pm 5^{\circ} \mathrm{C}$} & 4 & $5.75 \pm 2.50$ & $7.61 \pm 3.00$ & $5.48 \pm 2.31$ & $7.91 \pm 2.79$ \\
\hline & & 6 & $4.18 \pm 1.59$ & $9.15 \pm 1.99$ & $3.88 \pm 1.57$ & $9.35 \pm 2.47$ \\
\hline & & 8 & $1.65 \pm 1.61$ & $12.85 \pm 1.32$ & $1.53 \pm 1.68$ & $13.20 \pm 1.40$ \\
\hline \multicolumn{3}{|c|}{$\begin{array}{l}\text { Tek Kavrulmuş Leblebi } \\
\text { (Once roasted Chickpea) }\end{array}$} & $12.96 \pm 0.43$ & $0.83 \pm 0.15$ & $13.37 \pm 0.27$ & $0.77 \pm 0.18$ \\
\hline
\end{tabular}

Çiğ Tat

Farklı kavurma sıcaklık ve sürelerinin leblebilerin çiğ tadını çok önemli düzeyde $(p<0.0001)$ etkilediği tespit edilmiştir (Şekil 4). Buna göre en düşük çiğ tada sahip leblebi $200 \pm 5{ }^{\circ} \mathrm{C}$ ' de 8 dakika kavrulan leblebi (1.53), en yüksek çiğ tada (13.37) sahip leblebi ise tek kavrulmuş leblebi olduğu tespit edilmiştir (Çizelge 9).

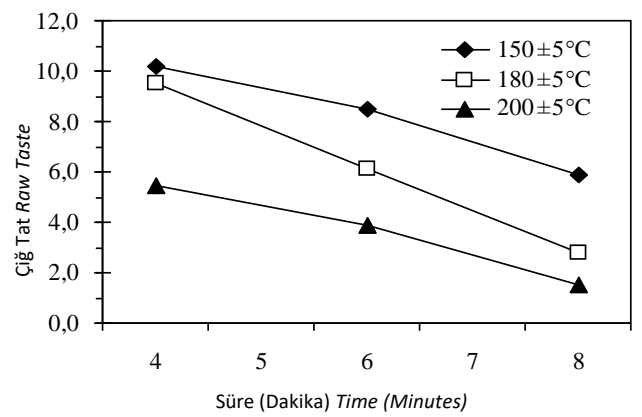

Şekil 4. Leblebilerin çiğ tat değişimi

Figure 4. Change the raw taste of roasted chickpeas

\section{Yanık Tat}

Farklı kavurma sıcaklık ve sürelerinin leblebilerin yanık tadını çok önemli düzeyde $(p<0.0001)$ etkilediği tespit edilmiştir (Şekil 5). Buna göre en düşük yanık tada sahip leblebi tek kavrulmuş leblebi (0.77), en yüksek yanık tada sahip leblebi (13.20) ise $200 \pm 5^{\circ} \mathrm{C}^{\prime}$ de 8 dakika kavrulan leblebi olduğu belirlenmiştir (Çizelge 9).

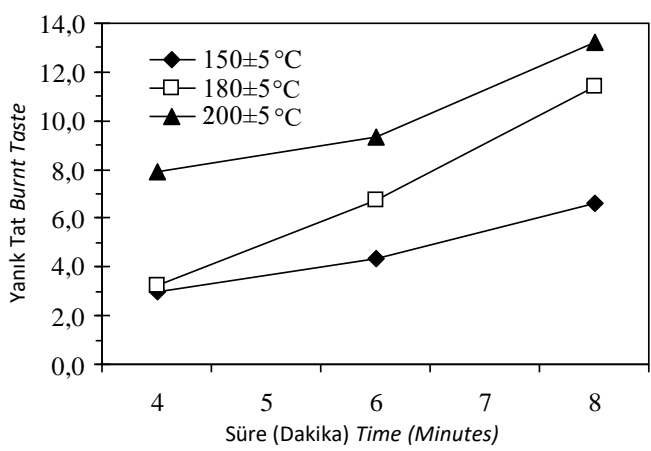

Şekil 5. Leblebilerin yanık tat değişimi

Figure 5. Change the burnt taste of roasted chickpeas

\section{Sonuçlar}

Leblebi, nohudun farklı sıcaklıklarda kavrulması ile elde edilen ülkemize özgü bir çerezdir. Leblebi yapımı sırasında nohutlar birçok Isıl işlemden ve dinlendirmelerden geçtikten sonra tek kavrulmuş leblebi haline gelmektedir. Piyasadan satın alınıp tüketilen leblebiler, çifte kavurmuş leblebilerdir. Çifte kavurma işlemi sırasında leblebiler kavurma sistemleri sayesinde ikinci ısıl işlemden geçirilir ve böylece leblebiye özgü hoş tat, 
koku ve albenisini arttıran fiziksel özellikler kazandırılmış olmaktadır.

Kimyasal analiz sonuçlarından kül, lif ve ham protein içeriklerinde istatistiksel bir değişiklik tespit edilmemiştir. Buna karşılık nem ve toplam nişasta içeriğinde önemli derecede azalma görülmüştür.

Kavurma süresince leblebi numunelerinde esmerleşme gözlenmiş̧ir. Bu esmerleşmenin nedeni indirgen şekerlerin aminoasitler veya peptidler gibi amino bileşikleri ile Maillard reaksiyonu vermesi sonucu veya şekerlerin sıcaklığın etkisi ile karamelleşmesi sonucu oluşabileceği düşünülmektedir.

Kavurma ile birlikte sertliğin azalmasının nedeninin leblebi numunelerinde önemli miktarda hava boşluğu bulunmasıdır. İkinci kavurma işleminde leblebilerdeki su, sıvı formdan gaz formuna geçmekte ve suyun buhar basıncı yükselmektedir. Kavurma işleminin devam etmesiyle birlikte buhar çıkışı sonucunda nişasta yapısından su kaybetmektedir. Bu da gözenekli bir yapının oluşmasına neden olmaktadır. Bu sayede leblebilerin tüketilebilir sertliğe ulaştığı belirtilmektedir.

Numunelerin duyusal analiz sonuçlarına göre; kavurma sıcaklık ve süresinin artması ile birlikte beneklilik değerinin arttığı buna karşılık beneklilik dışı rengin azaldığı gözlenmiştir. Bu artış leblebilerin çekiciliğinin artmasına vesile olmuştur. Kavurma sıcaklık ve sürelerinin artması ile çiğ koku ve çiğ tat özelliklerinin azaldığı, yanık koku ve yanık tat özelliklerinin ise arttığı gözlenmiştir. Duyusal analiz sonuçlarına göre, $180 \pm 5{ }^{\circ} \mathrm{C}^{\prime}$ de 8 dakika, $150 \pm 5{ }^{\circ} \mathrm{C}^{\prime}$ de 8 dakika ve $150 \pm 5{ }^{\circ} \mathrm{C}^{\prime}$ de 6 dakika kavrulan leblebilerin sırasıyla en çok beğenilen leblebiler oldukları ifade edilmektedir.

Ülkemiz leblebi üretimi ve ihracatı konusunda söz sahibi olmasına rağmen, leblebi standardı mevcut değildir. Bu çalışma ile tek kavrulmuş leblebilerin çifte kavrulmuş leblebi haline dönüştürülmesinde uygulanan sıcaklık ve süre standardize edilmeye çalışılmıştır.

Araştırmada elde edilen sonuçlara göre, kavurma sıcaklık ve sürelerinin leblebinin albenisini ve tüketilebilirlik değerini yükselttiği sonucuna varılmıştır. Leblebi yapım aşamalarından biri olan kavurma işlemi leblebi yapımı açısından önemli bir yer teşkil etmektedir.

\section{Ekler}

$\mathrm{Bu}$ çalışma, Süleyman Demirel Üniversitesi Bilimsel Araştırma Projeleri Koordinasyon Birimince 0917-YL-04 nolu proje olarak desteklenmiştir. Desteklerinden dolayı teşekkür ederiz.

\section{Kaynaklar}

Afacan N., 2000. Determination of the Important Parameters for High Quality WhiteRoasted Chickpea Production. Yüksek Lisans Tezi. The Middle East Technical University. Ankara.

Anonim, 1982. Türk Standartları Enstitüsü. Nohut. TS142.

AOAC, 1997. Official Methods of Analysis, $16^{\text {th }}$ ed. Arlington: Association of Official Analytical Chemists.

Arntfield, S., D., Murray, E., D., Ismond, M., A., H., 1985. The Influence of Processing Parameters on Food Protein Functionality. III. Effect of moisture content on the thermal stability of fababean protein. Canadian Institute of Food Science and Technology Journal, 18: 226-232.

Aydın, F., 2002. Nohudun Kullanımı ve Leblebi Üretimi. Hububat Ürünleri Teknolojisi Kongre ve Sergisi. Gaziantep.

Bilgir, B., 1976. Türk Leblebilerinin Yapılışı ve Bileşimi Üzerinde Araştırmalar. Ege Üniversitesi Ziraat Fakültesi Yayınlar No: 232. Ege Üniversitesi Matbaası. Bornova, İzmir.

Bozkurt, H., Göğüş, F., 1997. Food Quality Control Laboratory Manual. University of 
Gaziantep. Department of Food Engineering. ISBN: 975-7375-14-4. Gaziantep.

Chavan, J., K., Jawele, H., K., Shore, D., M., Jadhav, S., J., Kadam, S., S., 1983. Effect of presoaking treatments on the cooking quality of legume dhals. Indian Food Packer, 37: 78-81.

Coşkuner, Y., Karababa, E., 2004. Leblebi: a Roasted Chickpea Product as a Traditional Turkish Snack Food. Food Reviews International, 20, 3: 257-274.

Deshpande, S., S., Damodaran, S., 1990. Food legumes: chemistry and technology. In: Pomeranz. Y., ed. Advanced in Cereal Science and Technology, Vol. X. St. Paul, $\mathrm{MN}$ : American Association of Cereal Chemists, 147-241.

Gençkan, S., 1958. Türkiye'nin Önemli Nohut Çeşitlerinin Başlıca Vasıfları Üzerinde Araştırmalar. Ege Üniversitesi Ziraat Fakültesi Yayınları:1. Ege Üniversitesi Matbaası. Izmir.

Gülümser, A., 1988. Nohutun hasattan sonra değerlendirilmesi ve leblebi yapımı. Ondokuz Mayıs Üniversitesi, Ziraat Fakültesi Dergisi, 3 (2): 251-260.

Jang, J., K., Pyun, Y., R., 1996. Effect of moisture content on the melting of wheat starch. Starch, 48: 48-51.

Jambunathan, R., Blain, H., L., Dhindsa, K., S., Hussein, L., A., Kogure, K., Li-Juan, L., Youssef, M., M., 1994. Diversifying use of cool season food legumes through prosessing. Curr Plant Sci Biotechnol agric.,19: 98-112.

Jood, S., Bishnoi. S., Sharma, A., 1998. Chemical analysis and physico-chemical properties of chickpea and lentil cultivars. Nahrung, 42, 2: 71-74.

Kırbaşlar, G., F., 1998. Kavurma Sıcaklığının Fındığın Besin Değerine Etkisinin Incelenmesi. Doktora tezi. İstanbul Üniversitesi, İstanbul.

Köksel, H., Sivri, D.; Scanlon, M., G.; Bushuk, W., 1998. Comparison of physical properties of raw and roasted chickpea (leblebi). Food Research International, Vol. 31, No: 9: pp. 659-665.

Köroğlu, M., Okay, Y., Köksal, A., I.., 2000. Kavrulmuş Tuzlu Antepfıstığı Yapımında Kavurma Süresinin Bazı Kalite Özellikleri Üzerine Etkileri. Gıda, 25 (5): 337-340.

Labuza, P., P,.1982. Shelf Life Dating of Foods. ISBN 0-917-678-14-1. Minnesota.
Oosterrveld A., Voragen, A., G., J., Schols, H., A., 2003. Effect of roasting on the carbohydrate composition of Coffea arabica beans. Carbohydrate Polymers, 54: 183-192.

Özdemir, M., 2001. Mathematical Analysis of color changes and chemical Parameters of roasted hazelnuts. Doktora Tezi. Istanbul Technical University, İstanbul.

Redgwell, R., J., Trovato, V., Delphine, C., Fischer, M., 2002. Effect of roasting on degradation and structure features of polysaccharides in Arabica coffee beans. Carbohydrate Research, 337: 421-431.

SAS, 2003. SAS Version 9.1 by SAS Institute Inc., Cary, NC, USA.

Saklar, S., Ungan, S., Katnaş, S., 1999. Instrumental crispness and crunchiness of roasted hazelnuts and correlations with sensory assessment. Journal of Food Science, 64, 6: 1015-1019.

Scalon, M.,G., Segall, K., I., Cenkowski, S., 1999. The stiffness versus porosity relationship for infrared-heat trated (micronized) durum wheat grains. In Proceedings of Bubbles in Foods. Campbell, G. M., Webb, C., Pandiella, S.S. Nirangan, K.K. (eds.) Eagan press: St Paul, MN, pp. 283-290.

Singh, K. B., 1997. Chickpea (Cicer arientinum L.). Field Crops Research, 53: 161-170.

TÜik, 2016. http://www.tuik.gov.tr/PreTablo.do?alt_id=1001.

Tekeli, S., T., 1965. Ziraat Sanatları. Ankara Üniversitesi Ziraat Fakültesi Yayınları, 237. Yayın No: 77: 477-480.

Uluöz, M., 1965. Buğday, Un ve Ekmek Analiz Metotları. Ege Üniversitesi Ziraat Fakültesi Yayınları No: 57. Ege Üniversitesi Matbaası. İzmir.

Williams, P., C., Bhatty, R., S., Deshpande, S., S., Hussein, L., A., Savage, G., P., 1994. Improving nutritional quality of cool season food legumes. Curr Plant Sci Biotechnol Agric.,19: 113-129. 